периода - рост численности сельского населения и, не просто рост, а темпами, превышающими темпы роста городского населения [3].

В целом за 1897-1999 гг. общая численность населения Северной Осетии выросла в 3,4 раза, численность городского населения - в 7,7 раза, сельского - в 1,6 раза. Численность населения горной части республики сократилась почти на $2 / 3$, в то время как на равнине увеличилась в 4,2 раза.

Число городских поселений увеличилось с 2 до 13, а число сельских сократилось почти в 1,7 раза (в горах - в 1,9 раза, на равнине - в 1,4 раза). В то же время наблюдалось значительное увеличение средней людности сельских поселений (в 2,8 раза). Однако это увеличение произошло только за счет равнинной части: в то время как на равнине средняя людность увеличилась в 3,2 раза, в горах она снизилась в 3,9 раза.

$$
* * *
$$

1. Бадов А.Д., Тавасиев В.Х. Социально-демографические проблемы Север-ной Осетии. - Владикавказ: СОГУ, 1998.

2. Государственный архив Российской Федерации. Ф.1240, оп.60, д.44, л.110.

3. Тавасиев В.Х., Ревазов В.Ч. Население Северной Осетии в XX веке. - Владикавказ: Изд-во «Олимп», 2014. $-173 \mathrm{c}$.

4. Первая Всеобщая перепись населения Российской Империи, 1897. Кн. 68. Терская область. - СПб.: Издание Центрального Статистического Коми-тета Министерства Внутренних Дел, 1905.

5. Тавасиев Г.В., Тавасиев В.Х. Этнодемографические проблемы в Респуб-лике Северная Осетия-Алания// Современные проблемы науки и образо-вания. - 2014. - №6. - С.1511.

6. Тавасиев В.X. Социально-демографическое развитие Северной Осетии в XX веке. - Владикавказ: Издво «Олимп», 2013.

7. Тавасиев В.Х. Анализ численности населения Северной Осетии в XX ве-ке// Современные проблемы науки и образования.- Пенза: Издательский Дом «Академия Естествознания». 2013. №6. - С.830.

8. Тавасиев В.Х., Тавасиев Г.В. Экономические и социально-экологические проблемы городских поселений Республики Северная Осетия-Алания// Фундаментальные исследования. - 2015. - №11-7. C.1489-1492.

9. Тавасиев В.Х. Социально-демографическое развитие Северной Осетии в XX веке// Вестник университета (Государственный университет управле-ния), №23.- Москва, 2013. - С.282-286.

\title{
Трошина C.B.
}

Влияние средств массовой информации на социальное поведение молодёжи

Ульяновский государственньй педагогический университет имени И. Н. Ульянова (Россия, Ульяновск)

doi: $10.18411 / \mathrm{j}-02-2019-38$

idsp: ljournal-02-2019-38

\section{Аннотация}

В статье рассматривается значение социального поведения людей в жизни общества XXI века в аспекте влияния средств массовой информации. В фокусе внимания - молодёжь - социальная категория, наиболее вовлечённая в информационный поток. В статье приведены результаты диагностического исследования индикативных показателей социального поведения студенческой молодёжи Ульяновского государственного педагогического университета имени И. Н. Ульянова, доказывающего подверженность студентов негативному влиянию СМИ.

Ключевые слова: социализация, социальное поведение, саморегуляция, эмоциональное состояние, социальная активность, средства массовой информации.

\section{Abstract}

In article the value of social behavior of people in life of society of the 21 st century in aspect of influence of mass media is considered. In attention focus - youth - the social category which is most involved in the information flow. Results of diagnostic testing of indicative indicators of social behavior of student's youth of the Ulyanovsk state pedagogical 
university of I. N. Ulyanov proving susceptibility of students to negative impact of media are given in article.

Keywords: socialization, social behavior, self-control, emotional state, social activity, mass media.

Ко второму десятилетию XXI века в Российской Федерации сложилось развитое информационное общество. Его главный ресурс - информация - стал важнейшим личным и политическим правом человека, закреплённым в Конституции РФ [1].

О важности развития информационной среды свидетельствует проект постановления правительства, предусматривающий увеличение финансирования государственного проекта «Информационное общество (2011 - 2020 годы)» на 41,77 миллиарда рублей, опубликованный Министерством цифрового развития, связи и массовых коммуникаций Российской Федерации в январе 2018 года.

СМИ признаны четвёртой ветвью власти. С самого рождения средства массовой информации сопровождают человека на его жизненном пути: они служат средством общения, получения новых знаний, развлечения, являются рабочим материалом. Таким образом, одной из основных составляющих социализации человека в XXI веке составляет именно СМИ. А это значит, что средства массовой информации могут оказывать прямое влияние на выбор, мнение, мировоззрение человека, его психоэмоциональное состояние и, как следствие, его социальное поведение.

Подобному воздействию наиболее сильно подвержена молодёжь, главным спутником жизни которой является такой популярный вид СМИ, как Интернет. По результатам опроса, проведённого Всероссийским центром изучения общественного мнения 17 сентября 2018 года, доля пользователей СМИ, в частности интернетпользователей в России составляет $81 \%$ граждан. В том числе $65 \%$ выходят в сеть ежедневно. Среди россиян от 18 до 24 лет этот показатель составляет 97\%. Эти данные являются прямым показателем важности средств массовой информации в жизни молодёжи.

Однако воздействие СМИ имеет не только положительную сторону: По мнению исследователей, неконтролируемая свобода средств массовой информации, начавшаяся с конца 80-х, начале 90-х гг., привела к тому, что информация, передаваемая ими, стала нести в себе существенный отрицательный потенциал. Специалисты отмечают, что за последние шесть лет уровень девиантного поведения среди молодых людей под влиянием СМИ значительно повысился.

Игнорирование или несвоевременная реакция на проявление девиантного социального поведения среди молодёжи может обернуться возникновением очагов массовых общественных беспорядков и преступлений. Например, митинг «Жёлтых жилетов» во Франции в ноябре 2018 года перешёл в массовые беспорядки, сопровождающиеся драками, вандализмом, арестами и гибелью людей. Катализатором послужили сообщения и агитации в средствах массовой информации, за счёт которых увеличилось количество участников и уровень агрессии среди населения.

Именно поэтому одной их широких и важнейших задач социальных работников, а также специалистов смежных областей, является изучение влияния СМИ на социальное поведение людей, в особенности молодёжи, что обуславливает актуальность научного исследования.

С целью практического исследования данной проблемы были изучены тенденции социального развития молодёжи и её социологического анализа, а также проведена диагностика социального поведения студенческой молодёжи Ульяновского государственного педагогического университета имени И. Н. Ульянова [2; 5]. Определение характера социального поведения молодёжи УлГПУ проходило по трём основным индикативным показателям, которые были приняты как наиболее информативные: саморегуляция, эмоциональное состояние и социальная активность. 
Выборка исследования составила 50 студентов Ульяновского государственного педагогического университета в возрасте от 18 до 25 лет.

1.Методика диагностики саморегуляции молодёжи «Стиль саморегуляции поведения» (ССПМ) [4].

Методика представляет собой опросник, созданный в 1988 году в Психологическом институте РАО в лаборатории психологии саморегуляции.

Опросник ССПМ состоит из 46 утверждений и работает как единая шкала «Общий уровень саморегуляции», которая характеризует уровень сформированности системы саморегуляции произвольной активности человека.

При проведении расшифровки ответов респондентов было выявлено, что такие шкалы, как «Моделирование», отвечающая за развитость представлений о внешних и внутренних значимых условиях, степени их осознанности, детализированности и адекватности (3 балла в сумме), и «Оценивание результатов», характеризующая развитость и адекватность оценки испытуемым себя, результатов своей деятельности и поведения (4 балла в сумме), имеют низкие показатели.

При этом шкалы «Планирование», характеризующая особенности выдвижения и удержания целей, сформированность осознанного планирования деятельности (7 баллов в сумме), и «Программирование», подразумевающая развитость осознанного программирования своих действий (8 баллов в сумме), имеют достаточно высокие показатели.

Результаты диагностики саморегуляции показали, что студенты УлГПУ не могут в полной мере регулировать своё поведение в сложных ситуациях: они легко поддаются давлению со стороны, ими нередко управляют эмоции, часто возникает трудность в принятии взвешенного решения, склонны к искажённому восприятию реального положения дел.

Такие факторы приводят к увеличению риска попадания под негативное влияние средств массовой информации, окружающих студенческую молодёжь. Последние, в свою очередь, могут спровоцировать состояние аффекта у молодых людей, привести к необдуманным поступкам, натолкнуть на противоправные действия и другим формам девиантного социального поведения.

2.Методика диагностики эмоционального состояния молодёжи Е. П. Ильина [3].

Данная методика представляет собой опросник «Характеристики эмоциональности», состоящий из 32 вопросов с выбором ответов «Да» и «Нет». С помощью данного опросника индикативный показатель исследуется с точки зрения 4 главных аспектов: эмоциональная возбудимость, длительность и интенсивность эмоций, негативное влияние эмоций.

Обобщив ответы респондентов и выделив наиболее часто выбираемые из них, были получены следующие результаты, представленные графически (рис.1).

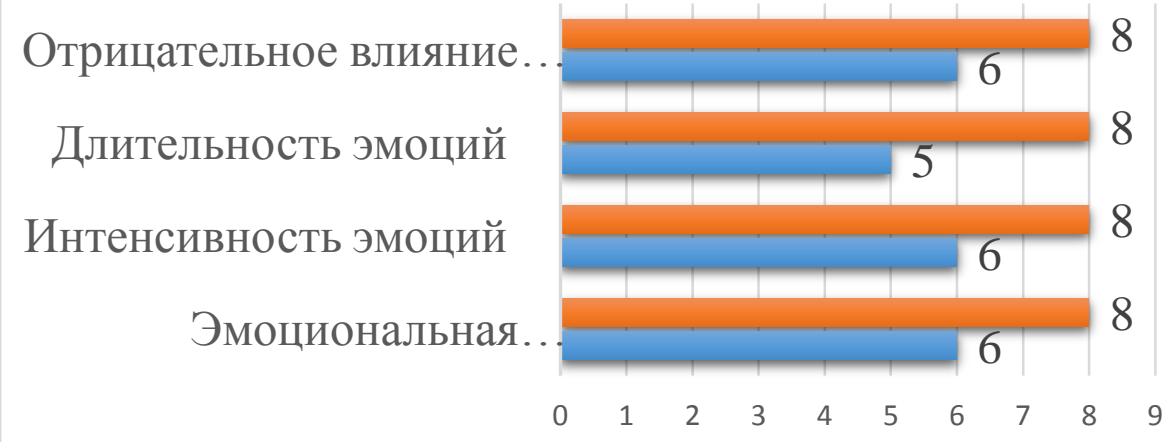

Всего баллов $\square$ Колличество полученных баллов

Рис. 1 - Результатьл диагностики «Характеристики эмоџиональности» 
Эти показатели свидетельствуют о высокой выраженности данных аспектов в эмоциональном состоянии молодёжи.

В частности, самый значимый для исследования аспект - «Отрицательное влияние эмоций» диагностирует не только уровень негативных эмоциональных переживаний, воздействующих на внутреннее психологическое здоровье человека, но степень возможности перехода человека в состояние аффекта, под воздействием которого социальное поведение человека приобретает девиантный характер.

Анализ результатов показал, что СМИ, одним из способов передачи и усвоения информации которых является воздействие на эмоциональное поле человека, также могут негативно сказаться на социальном поведении студентов УлГПУ, не имеющих достаточного навыка контроля над своей эмоциональной сферой и не умеющих сортировать вредоносный информационный поток от полезного.

3.Методика диагностики социальной активности молодёжи «Социальная активность глазами студентов УлГПУ».

Для изучения социальной активности молодёжи, как одной из неотъемлемых составляющих социального поведения, была разработана авторская анкета из 10 вопросов: развёрнутых и предполагающих выбор одного варианта ответа.

По результатам анкетирования было выявлено, что 90\% респондентов знают о значимости социального поведения в общественной среде и роли социальной активности в ней, однако лишь $60 \%$ опрошенных студентов Ульяновского государственного педагогического университета принимают активное участие в социально-значимых мероприятиях. При этом 30\% респондентов поделились, что участвуют в подобных мероприятиях редко, только когда появляется интересующее их предложение. 10\% опрошенных не интересовались этой деятельностью в принципе. Следует отметить, что информация, поступающая предстоящих мероприятиях, не покрывает полностью поле интереса молодёжи, из-за чего они не принимают в них участие.

На вопрос «Откуда вы узнаёте о проводимых социально-значимых мероприятиях?», ожидаемо большое количество голосов было получено за ответ «социальные сети» (70\% респондентов), остальные узнают о событиях от друзей (30\% опрошенных). Это подтверждает тот факт, что Интернет является главным источником информации, с которым работает молодёжь.

Исходя из предыдущего вопроса, респондентам было предложено принять участие в создании контента для социальных сетей медиацентра «Улей», посвящённого проводимым социально-значимым мероприятиям как в УлГПУ, так и за его пределами, который был бы значим для студентов и смог повысить их интерес. 40\% опрошенных заинтересовались данной идеей, 20\% - хотели бы, но сомневаются в своих силах. Итого - $60 \%$ опрошенных, давших положительный ответ, против 40\%, высказавшихся против.

Диагностика индикативного показателя «социальная активность» молодёжи показала, что далеко не все студенты привлечены к данному виду деятельности, хотя многие из них испытывают потребность в самореализации. Чтобы предотвратить возможное возникновение негативного влияния одного из неотъемлемых компонентов социального поведения молодёжи, необходимо провести работу по повышению уровня социальной активности студентов, тем более, что многие из студентов проявили готовность к соучастию в этом процессе.

Таким образом, в ходе проведения первичной диагностики социального поведения молодёжи, был выявлен низкий уровень саморегуляции, отсутствие эмоциональной стабильности, а также определён уровень вовлеченности студентов в социальную активность, показатель которого оказался ниже высокого. Для предотвращения негативного влияния средств массовой информации на индикативные показатели, и включения СМИ как эффективного инструмента для их повышения и 
улучшения, необходима разработка и реализация социального проекта по корректированию социального поведения студенческой молодёжи посредством СМИ.

$$
\text { *** }
$$

1. Конституция Российской Федерации: принята всенародным голосованием 12 декабря 1993 г. (с изм. и доп. от 05.02.2014) // Собрание Законодательства, 2014, ст. 29.

2. Жаданов, А. Ю. Тенденции социального развития молодежи в условиях растущего влияния информационно-коммуникационных технологий // Историческая и социально-образовательная мысль. - 2013. - №4 (20). - C. 165-168.

3. Ильин, Е. П. Эмоции и чувства // Мастера психологии. - СПб: Питер, 2001. - 752 с.

4. Моросанова, В. И. Стилевая саморегуляция поведения человека // Вопросы психологии. -2000 . №2. - C. 118-127.

5. Сергеев, Р. В. Молодежь и студенчество как социальные группы и объект социологического анализа // Вестник Адыгейского государственного университета. Серия 1: Регионоведение: философия, история, социология, юриспруденция, политология, культурология. - 2010. - С. 127-133. 